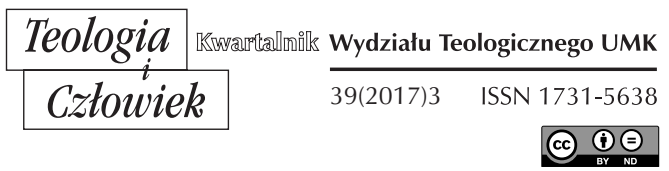

KS. IRENEUSZ ŚWIĄTEK*

WŁOCLAWEK

\title{
UŚWIĘCENIE CZASU W GŁÓWNYCH ŚWIĘTACH BIBLIJNEGO IZRAELA
}

\section{WSTĘP}

Zagadnienie czasu w perspektywie przestrzeni liturgicznej Izraela jest ważne i w bardzo konkretny sposób wysuwa się przed porządek przestrzeni i zewnętrznej obrzędowości. Celem tego artykułu jest przedstawienie głównych świąt biblijnego Izraela, takich jak: Paschy, Święta Tygodni i Święta Namiotów w ich relacji do Święta Świąt, czyli Szabatu. Szabat jest czasem uświęconym, który w sposób istotny wpływa na kształtowanie się charakteru wspomnianych Świąt. Wpływ ten ma wielopłaszczyznowy wymiar realizujący się w formowaniu określonej świadomości przeżywanego czasu. Studium tego oddziaływania jest poprzedzone prezentacją pojęcia czasu w Biblii oraz jego relacji do przestrzeni.

* Ks. Ireneusz Świątek, mgr lic. teologii biblijnej, prezbiter diecezji włocławskiej. Licencjonowany przewodnik po Ziemi Świętej (irek_s@poczta.onet.pl). 


\section{POJĘCIE CZASU W BIBLII}

Biblia rozpoczyna swoje opowiadanie o Bogu i człowieku informacją o charakterze czasowym": „Na początku Bóg stworzył niebo i ziemię” ( $\operatorname{Rdz} 1,1)$. Słowo Boże nie pozostawia też wątpliwości, kto jest stwórcą i władcą czasu: „A potem Bóg rzekł: «Niechaj powstaną ciała niebieskie, świecące na sklepieniu nieba, aby oddzielały dzień od nocy, aby wyznaczały pory roku, dni i lata (Rdz 1,14). Pismo święte ukazuje Stwórcę, który wchodzi w sposób realny w historię człowieka, czyniąc z niej tym samym historię niezwykłą, historię świętą.

W języku Biblii nie znajdujemy jednak ogólnego terminu odpowiadającego w treści słowu czas, ani też konkretnych określeń oznaczających teraźniejszość, przeszłość czy przyszłość. Czas nie był tam postrzegany jako coś abstrakcyjnego, ale odnosił się do wydarzeń, które trwały krócej lub dłużej² Pojęcia, które są najczęściej tłumaczone jako czas w ST to עִת,

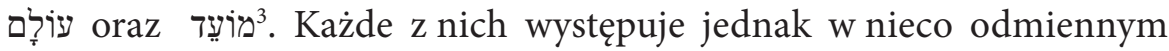
znaczeniu. Wyraz úÅò wskazuje zwykle na czas bieżący, albo odnosi się do czasu zachodzącego $\mathrm{w}$ trakcie zaistniałego wydarzenia ${ }^{4}$. Ten rodzaj

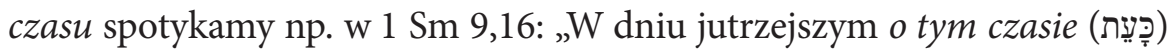
poślę do ciebie człowieka z ziemi Beniamina"5. Kolejne słowo - עוֹֹ - odnosi się do bliżej niedającego się określić, co do długości trwania, czasu przyszłoścí. W takim znaczeniu występuje m.in. w Mi 4,7: „Chromych uczynię Resztą, a wyrzutków - narodem mocnym. I będzie królował Pan

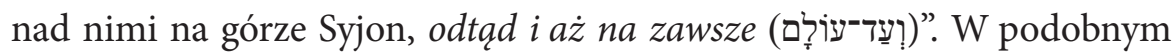
znaczeniu עוָֹֹ odnosi się także do czasu przeszłości. Tak jest np. w Koh

${ }^{1}$ Pismo święte podobnie kończy swoją opowieść w ostatniej księdze Nowego Testamentu informacją: „Zaiste przychodzę niebawem” (Ap 22,20).

2 Por. P.J. Achteimer, J. Unterman, Czas, w: Encyklopedia biblijna, red. P.J. Achtemeier, tłum. A. Gocłowska, Warszawa 1999, 180.

${ }^{3}$ Por. Tamże.

${ }^{4}$ Zob. T. Kronholm, עy, weological Dictionary of the Old Testament, red. G.J. Botterweck, H. Ringgren, H.-J. Fabry, t. 11, Grand Rapids 2001, 446-447.

${ }^{5}$ W podobnym znaczeniu występuje również w: Koh 1,1-8; Ezd 10,13; 2 Krn 24,11 .

${ }^{6}$ Zob. H.D. Preuss, עוֹדָ, Theological Dictionary of the Old Testament, red. G.J. Botterweck, H. Ringgren, H.-J. Fabry, t. 10, Grand Rapids, 1999, 534-536. 
1,10: „Jeśli jest coś, o czym by się rzekło: patrz, to coś nowego» - to już

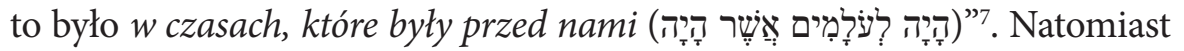
pojęcie מעוֹ używane jest do określania czasu, dotyczącego konkretnych wydarzeń $^{8}$. Odnajdujemy je np. w Kpł 23,2.4: „Mów do Izraelitów i po-

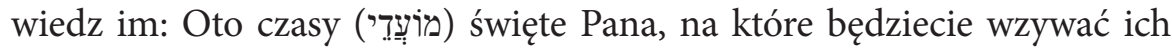

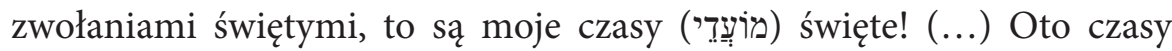

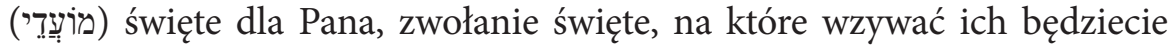

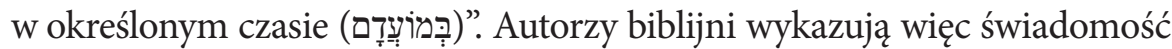
występowania wielu rodzajów czasu. Kiedy poddajemy analizie biblijne obrazy czasu zauważamy, że jego rozumienie znacznie wykraczało poza następstwo wydarzeń dokonujących się jedne po drugich. Było to spowodowane tym, że Biblia wyrażała większe zainteresowanie świętością czasu, niż świętością przestrzeni ${ }^{9}$.

\section{CYKLE CZASOWE BIBLIJNEGO IZRAELA}

W Biblii odnajdujemy także cykliczne postrzeganie czasu. Wskazuje na to, pojawiająca się już w Księdze Rodzaju, formuła podkreślająca świadomość rozumienia 24-godzinnego dnia: „I tak upłynął wieczór i poranek” ( $\operatorname{Rdz} 1$ 1,5.8.13.19.23.31). Natomiast Psalm 55 mówi o trzyczęściowym podziale dnia: „Wieczorem, rano i w południe narzekam i jęczę, a głosu mego On wysłucha” (Ps 55,18). Znany jest też podział nocy na trzy części tzw. „straże” (zob. Wj 24; Sdz 7,9; Lm 2,9). Obecność podobnych, dotyczących dnia i dni, niespełna 2000 odnośników na kartach Biblii, potwierdza nierozerwalny związek dobowego cyklu z życiem codziennym człowieka $^{10}$.

Następnym cyklem opartym na dziele stworzenia, ukazanym w pierwszej księdze Pisma Świętego, jest tydzień. Składa się on z sied-

7 Tamże, 533-534.

${ }^{8}$ Zob. K. Koch, מוֹער, we Theological Dictionary of the Old Testament, red. G.J. Botterweck, H. Ringgren, H.-J. Fabry, t. 8, Grand Rapids 1997, 167-173.

9 Zob. Słownik symboliki biblijnej, red. L. Ryken, J.C. Wilhoit, T. Longman II, Warszawa 1998, 123.

${ }_{10}$ Zob. Tamże. 
miu dni ${ }^{11}$. Nie zostały one nazwane, ale ponumerowane od pierwszego do szóstego. Dzień siódmy, jako ukoronowanie tygodnia został nazwany szabatem od hebrajskiego słowa oznaczającego odpoczać. Informuje o tym Rdz 2,2-3: „A gdy Bóg ukończył w dniu szóstym swe dzieło, nad którym

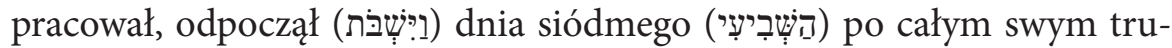
dzie, jaki podjął. Wtedy Bóg pobłogosławił ów siódmy dzień i uczynił go

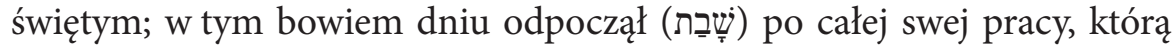
wykonał stwarzając" ( $\mathrm{Rdz} 2,2-3)$.

Po cyklu tygodniowym zauważamy cykl miesięczny. Słowem używanym na określenie miesiąca w Biblii jest חדฺ̣ (księżyc, nów księżyca) ${ }^{12}$. Nów księżyca był dniem świątecznym, natomiast ważne święta przypadały na połowę miesiąca, czyli na pełnię księżyca ${ }^{13}$. Z 250 odnośników, które odnajdujemy w Biblii mówiących o tym cyklu, większa część dotyczy tekstów opowiadających o obrzędach religijnych, w których oddawano cześć samemu Stwórcy, przez co czas nabierał charakteru świętego ${ }^{14}$.

Postrzeganie cyklu roku w świecie biblijnym opierało się na wegetacji upraw, począwszy od zasiewu, przez wzrost, a skończywszy na zbiorach. Z cyklem tym, o którym Biblia wspomina aż 750 razy, związane były również doroczne święta (głównie trzy święta pielgrzymkowe: Pasach, Szawuot i Sukkot) ${ }^{15}$.

Autor Psalmu 90 ujawnia ostatni przedział czasu, który występuje w Biblii, tj. okres ludzkiego życia: „Miarą naszego życia jest lat siedemdziesiąt lub, gdy jesteśmy mocni, osiemdziesiąt" (Ps 90,10). Do niego nawiązuje również Kohelet: „Pokolenie przychodzi i pokolenie odchodzi" (Koh 1,4). Królestwo ducha o którym biblia opowiada powoduje, że $\mathrm{w}$ istocie przeżywania czasu zaciera się różnica między poszczególnymi fragmentami czasu: chwilą, godziną, epokąa ${ }^{16}$. Psalmista powie wręcz:

${ }^{11}$ Hebrajski termin שֶׁבֶ, który jest odpowiednikiem słowa tydzień dosłownie oznacza siedem.

12 Zob. Rdz 7,11; 8,3-4; Lb 20,29; Pwt 21,13.

${ }_{13}$ Zob. 1Sm 20,5; 18,24; 2Krl 4,23; Iz 1,13-14; Ps 81,4.

14 Zob. Słownik symboliki biblijnej, 123.

15 Por. Tamże, 124.

${ }_{16}$ Zob. R. de Vaux, Instytucje Starego Testament, tłum. T. Brzegowy, t. 1 i 2, Poznań 2004, 197. 
„Tysiąc lat w Twoich oczach jest jak wczorajszy dzień, który minął, niby straż nocna" (Ps 90,40).

Wobec powyższego zauważamy, że biblijna koncepcja czasu związana jest nierozerwalnie z YHWH, który stoi u jego początku, a życie ludzkie nabiera sensu tylko wtedy gdy w każdej chwili jest ukierunkowane na YHWH. Kohelet wyraża to stwierdzeniem: „Wszystko ma swój czas i jest wyznaczona godzina na wszystkie sprawy pod niebem" (Koh 3,1). Ten starotestamentalny mędrzec poucza, że w pryzmacie kruchości ludzkiego życia, zobaczenie oczami Bożymi cykliczności wydarzeń w nim następujących daje możliwość odkrycia czasu jako areny ludzkiej aktywności i związane z tym przekonanie, że Bóg „uczynił wszystko piękne w swoim czasie" (Koh 3,11). Poszukiwanie więc prawdziwej mądrości w życiu człowieka, powinno iść w kierunku znajomości odpowiedniego czasu na wszystko (zob. Koh 8,6). Należy tak przeżywać rzeczywistość czasu ziemskiego, aby nabierał on znaczenia transcendentnego, świętego. (zob. Ps 90,12).

\section{CZAS A PRZESTRZEŃ}

Wyjątkowość podejmowanej przez Słowo Boże problematyki czasu, nadają jej już pierwsze słowa Księgi Rodzaju: „na początku” (Rdz 1,1). Zanim pojawiła się mowa o przestrzeni, słyszymy informację o czasie. Czas dla Biblii jest tym, co wypełnia przestrzeń, co nadaje jej sens, stąd księga ta bardziej troszczy się o historię niż o geografię. Bardziej koncentruje się na dziejach pokoleń i wydarzeniach, pozostawiając nieco na uboczu relacje o krajach lub rzeczach. Dla lepszego zrozumienia opisywanych przez Biblię obrazów, przywiązany do przestrzeni czytelnik zauważa, że czas ma dla życia znaczenie wcale nie mniejsze, a czasem nawet większe niż przestrzeń.

Idąc za takim rozumieniem istoty czasu Abraham Joshua Heschel powie, że judaizm jest religią dążącą do uświęcenia $c z a s u^{17}$. Przyznaje on, że uzyskiwanie władzy nad światem zgodnie z zaleceniem Rdz 1,28 jest na pewno jednym z głównych zadań człowieka. Problem zaczyna się jednak

17 Por. Tamże, 31. 
wtedy, gdy człowiek pogrąża się coraz bardziej w królestwie przestrzeni, zapominając o królestwie czasu ${ }^{18}$. Prawdą jest, że w czynieniu sobie ziemi poddanej człowiek wykorzystuje czas, by pozyskać przestrzeń, jednak to czas, a nie przestrzeń jest „sercem istnienia” ${ }^{19}$. Czas jest tym wymiarem ludzkiego życia, w którym spotyka on Boga stając się świadomym tego właściwego czasowi dynamizmu - każda chwila jest niczym akt stworzenia, w której otwarte zostają nowe możliwości do ostatecznego spełnienia się człowieka. To czas gwarantuje przestrzeni obecność Boga bowiem charakter świętości nie należy do natury rzeczy, ale jest wartością dodaną, użyczoną im przez akt uświęcenia. To właśnie jest swoiste novum, jakie przyniósł judaizm, mianowicie że idea świętości przesuwała się w czasie z dziedziny natury do dziedziny historii, wędrowała od co do kiedy. Fizykalna dosadność przestrzeni i rzeczy, mimo że dominuje w ludzkiej percepcji otaczającego świata i własnej egzystencji, nie może być do nich zredukowana, rzeczy są bowiem brzegiem, podróż zaś odbywa się gdzieś między nimi - w czasie $^{20}$. Ważną cechą judaizmu jest to, że pokazuje on jak bardzo idea świętości jest osadzona w czasie, choćby w kontekście świętych wydarzeń, zaś sam żydowski rytuał można porównać do sztuki znaczących form w czasie, czy wręcz architektury samego czasu. Większość jego obrzędów zależy od określonych godzin dnia i pór roku ${ }^{21}$.

\section{SZABAT JAKO FUNDAMENT UŚWIĘCENIA CZASU}

Mówiąc o uświęceniu czasu w głównych świętach biblijnego Izraela musimy najpierw zauważyć święty dzień Szabatu, stojącego u podstaw i gwarantu idei czasu uświęconego, ustanowionego przez Boga ${ }^{22}$. W 23 rozdziale Księgi Kapłańskiej znajdujemy kalendarz świąt Izraela (w tym trzech interesujących nas świąt pielgrzymkowych), których katalog rozpo-

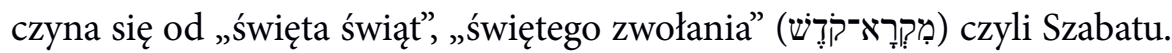

18 Por. Tamże, 23.

19 Por. Tenże, Man Is Not Alone. A Philosophy of Religion, New York 1951, 200.

${ }^{20}$ Zob. A.J. Heschel, Szabat i jego znaczenie dla współczesnego człowieka, tłum. H. Halkowski, Kraków 2009, 151.

${ }^{21}$ Zob. Tamże, 31, 131.

${ }^{22}$ Por. G. Kołodziej, Sacrum Szabatu, „Łódzkie Studia Teologiczne” 5 (1996), 93. 
Dzień ten, sam będąc świętem powtarzającym się co tydzień, skupia w sobie wszystkie inne święta przypadające na róże pory roku ${ }^{23}$. W tym kontekście warto zauważyć, że chociaż święta upamiętniają wydarzenia, które zdarzyły się w czasie, to data wyznaczona dla każdego nich w kalendarzu jest określona przez cykle przyrody. Dużą rolę w żydowskim kalendarzu odgrywa pełnia księżyca (Pascha, Święto Szałasów). Daty wszystkich świąt są nierozłącznie powiązane $\mathrm{z}$ nowiem księżyca, który zawsze stoi u początku każdego miesiąca ${ }^{24}$. Paradoksalnie, szabat jest świętym dniem, który jest całkowicie niezależny od miesiąca, a tym samym niezależny od faz księżyca. Data szabatu określana jest wyłącznie przez akt stworzenia, a w świetle tego jest on dniem będącym niejako poza porządkiem natury, w której stworzone ciała niebieskie odgrywają rolę zegara ${ }^{25}$.

Misją Szabatu jest uświęcenie bardziej czasu niż przestrzeni. Sześć dni w tygodniu oddane jest służbie rzeczom i przestrzeni, zaś sam dzień Szabatu jest „zaproszeniem do uczestnictwa w tym co wieczne w czasie, do zwrócenia się od rezultatu stworzenia - do tajemnicy stworzenia, od świata stworzonego - do stworzenia świata” ${ }^{26}$. Szabat to swoisty rodzaj czasu „ontologicznie różnego" od „reszty” czasu. Podstawą tego stwierdzenia jest jego uświęcenie przez samego YHWH (zob. Rdz 2,3) i nadanie mu autonomii względem reszty stworzenia ${ }^{27}$. Wydaje się czymś niezwykłym, że słowo קִּ (święty), które oddaje tajemnice i majestat $\mathrm{YHWH}^{28}$, odnosi się w pierwszym rzędzie do czasu Szabatu: „I pobłogosławił Bóg siódmy dzień i uczynił

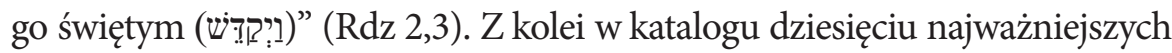
słów (drogowskazów) danych człowiekowi na Synaju przez YHWH, pojęcie קִּ (święty), odnosi się tylko do jednego z nich, do Szabatu:

${ }^{23}$ Zob Kpł 23,1-44.

${ }^{24}$ Zob. P.J. Achteimer, J. Unterman, Czas, w: Encyklopedia biblijna, 180.

${ }^{25}$ B.W. Matysiak, Szabat dniem uświęcenia ludu JHWH, w: Bóg jest miłościa 1J 4,16. Studia dla Księdza Profesora Józefa Kudasiewicza $w$ 80. rocznicę urodzin, red. Waldemar Chrostowski, Warszawa 2006, 291-293.

${ }^{26}$ Por. A.J. Heschel, Szabat, 33-34

27 Zob. Komentarz do: Bereszit 2:3, w: Tora Pardes Lauder. Księga Pierwsza Bereszit, red. S. Pecaric, tłum. S. Pecaric, E. Gordon, t.1, Kraków 200116; I. Grunfeld, Szabat, tłum. I. Mańka-Marcisz, Kraków 2011, 8.

${ }^{28}$ or. J. Kudasiewicz, Poznawanie Boga Ojca. Szkice z teologii biblijnej, t. 1, Kielce 2000, 286. 
${ }^{8}$ Pamiętaj o dniu szabatu, aby go uświęcić (לְְ? $) .{ }^{9}$ Sześć dni będziesz pracować i wykonywać wszystkie twe zajęcia. ${ }^{10}$ Dzień zaś siódmy jest szabatem ku czci Pana, Boga twego. Nie możesz przeto w dniu tym wykonywać żadnej pracy ani ty sam, ani syn twój, ani twoja córka, ani twój niewolnik, ani twoja niewolnica, ani twoje bydło, ani cudzoziemiec, który mieszka pośród twych bram. ${ }^{11} \mathrm{~W}$ sześciu dniach bowiem uczynił Pan niebo, ziemię, morze oraz wszystko, co jest w nich, w siódmym zaś dniu odpoczął. Dlatego pobłogosławił Pan dzień szabatu i uznał go za

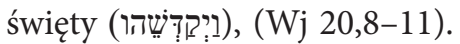

Szabat wskazuje na trzy aspekty uświęcenia czasu, które są dostrzegalne także w świętach pielgrzymkowych. Są to: celebracja stworzenia i wyzwolenia, eschatologia oraz znak przymierza ${ }^{29}$.

Biblijne uzasadnienie szabatu wynika, z jednej strony, $\mathrm{z}$ aktu stwórczego YHWH (zob. Wj 20,9-11) ${ }^{30}$, z drugiej zaś, z dzieła wyzwolenia narodu z niewoli egipskiej (zob. Pwt 5,12-15) ${ }^{31}$. O celebracji stworzenia opowiada opis zakończenia aktu stwórczego, przedstawiony w $\mathrm{Rdz} 1,31-2,2$ :

${ }^{31}$ Bóg widział, że wszystko, co uczynił, było bardzo dobre. I tak upłynął wieczór i poranek - dzień szósty. ${ }^{1} \mathrm{~W}$ ten sposób zostały ukończone niebo i ziemia oraz wszystkie jej zastępy [stworzeń]. ${ }^{2} \mathrm{~A}$ gdy Bóg ukończył w dniu szóstym swe dzieło, nad którym pracował, odpoczął dnia siódmego po całym swym trudzie, jaki podjął.

W powyższym fragmencie zauważamy, że Szabat następuje po szóstym dniu, w którym jest mowa o akcie stwórczym wszystkich istot żyjących, z człowiekiem jako ich ukoronowaniem. Z użytego w tekście słowa וַיְכַל, tłumaczonego jako „ukończył” wynika także, że YHWH swego dzieła „zaprzestał”32. To zaś sugeruje, że praca została przerwana, odroczona i nie ukończona, by celebrować stworzenie, kontemplować je

${ }^{29}$ Por. K. Strzelecka, Szalom, Warszawa 1987, 156-159; E. Zając, Judaizm jako religia uświęcająca czas, „Ethos” 99 (2012), 52.

${ }^{30}$ Zob. S.P. De Vries Mzn., Obrzędy i symbole Żydów, tłum. A. Borowski, Kraków 2004, 99.

${ }^{31}$ Por. N. Kameraz-Kos, Święta i obyczaje Żydowskie, Warszawa 1997, 27.

32 Zob. Komentarz do: Bereszit 2:2, w: Tora Pardes Lauder. Księga Pierwsza Bereszit, 14-16. 
oraz przyjąć jako dar YHWH ${ }^{33}$. W tym dniu zakazana jest wszelka praca. W nakazie tym, chodzi o coś znacznie więcej niż tylko fizyczną bierność. Konsekwencją dzieła stworzenia jest to, że człowiek został władcą zarówno w porządku ciała, jak i duszy, miał czynić sobie ziemię poddaną (zob. Rdz 1,28). W jego ręce złożono materiał, przez co stał się on posiadaczem, zarządcą, przetwórcą, ale nigdy stwórcą. Panowanie człowieka nad naturą, zgodnie z zaleceniem Stwórcy, w kontekście Szabatu nie jest więc absolutne. Zaprzestanie wszelkich twórczych działań tego dnia ${ }^{34}$ sprawia, że Izraelita jest niejako zmuszony opuścić tron swej rzekomej władzy, uznając nad sobą władzę i panowanie YHWH. Zatem istotą powstrzymywania się od pracy podczas szabatu jest więc nabieranie dystansu wobec roli, jaką człowiek posiada w odtwórczym panowaniu nad materią, kontemplacja dzieła stworzenia a nade wszystko uświęcenie czasu ${ }^{35}$. Celebracja stworzenia i wyzwolenia dostrzegalna jest również w pielgrzymkowych świętach biblijnego Izraela ${ }^{36}$.

W swym wymiarze eschatologicznym, Szabat charakteryzuje się otwartością na wieczność, a jego świętowanie sprawia, że człowiek staje się już niejako jej uczestnikiem. Izrael jest zatem związany z wiecznością, dlatego jeśli nawet przez sześć dni tygodnia poświęca się sprawom ziemskim, to jego dusza należy do dnia siódmego ${ }^{37}$.

Opowiadając o dniu siódmym, autor natchniony nie przytacza już formuły, która pojawiała się cyklicznie po ukończeniu każdego dnia: „I tak upłyną wieczór i poranek..."38. Według tradycji żydowskiej, noc dzieląca dzień szósty od siódmego (czyli dnia Szabatu), także była dniem. Stało się tak ponieważ Bóg chciał wybawić człowieka od śmierci, która przyszła na niego w dniu szóstym, jako konsekwencja jego grzechu. To Szabat

33 Por. K. Strzelecka, Szalom, 157.

${ }^{34}$ Człowiek ma nie tylko sam powstrzymywać się od pracy, ale także innym pozwolić nie pracować (por. Pwt 5,12-15).

35 Zob. L. Ruppert, Symbole im Alten Testament, w: Freude am Gottesdienst, red. J. Schreiner, Stuttgart 1983, 100; S.P. De Vries Mzn., Obrzędy i symbole Żydów, 100; I. Grunfeld, Szabat, 114.

${ }^{36}$ Zob. J. Klinkowski, Idea przestrzeni, czasu i człowieka w Biblii, „Legnickie Wiadomości Diecezjalne” 16 (2007) 2, 83.

37 Por. J. Schreiner, Die Zehn Gebote im Leben des Gottesvolkes, München 1988, 74.

38 Zob. Rdz 1,3;6;13;19;23;31. 
stając się żywą obecnością Boga, spowodował wstawienie się za człowiekiem, aby ten mógł mieć życie i być zbawiony ${ }^{39}$. Taki też jest właśnie cel i oczekiwanie każdego Szabatu. W Rdz 2,3 słowo iÇòÂùÒåÉú (odpoczął, aby uczynić) sugeruje jakieś niedokończenie dzieła. Szabat nie jest zatem kresem sam w sobie, ale jest ukierunkowany na szabat przyszłego świata. W sposób podobny ten eschatologiczny aspekt Szabatu zauważamy we wszystkich świętach biblijnego Izraela. Wydarzenia przeszłe, są aktualizowane $\mathrm{w}$ teraźniejszości, wskazują jednak w sposób zdecydowany na przyszłość ${ }^{40}$.

O trzecim aspekcie uświęcenia czasu w Szabacie informuje nas Księga Wyjścia: „Potem tak rzekł Pan do Mojżesza: «Powiedz Izraelitom: Przestrzegajcie pilnie moich szabatów, gdyż to jest znak między Mną a wami dla wszystkich waszych pokoleń, by po tym można było poznać, że Ja jestem Pan, który was uświęcam" (Wj 31,12-13). Szabat staje się też znakiem przymierza między stworzeniem a Stwórcą. I ten element odnajdujemy we wszystkich świętach Izraela. Podczas posiłku rozpoczynającego świętowanie następuje błogosławieństwo chleba (wyrażającego wdzięczność dla YHWH jako jego dawcy) i wiana (będącego znakiem radości). Nieodłącznym elementem świętowania jest również czytanie Tory, która pełni rolę pieczęci przymierza ${ }^{41}$.

\section{TRZY ŚWIĘTA}

Sięgając do czasów Synajskich zauważamy, że wtedy świętowanie nie było związane z konkretnym miejscem. Pan oznajmił Mojżeszowi: „Uczynisz Mi ołtarz z ziemi i będziesz składał na nim twoje całopalenia, twoje ofiary biesiadne z twojej trzody i z bydła na każdym miejscu, gdzie każę ci wspominać moje imię. Przyjdę do ciebie i będę ci błogosławił." (Wj 20,24). Z czasem jednak to objawianie się Boga w przestrzeni powodowało jej uświęcenie. Miejscem, które nabrało szczególnego znaczenia była świątynia jerozolimska z jej centralnym miejscem: świętym świętych

\footnotetext{
${ }^{39}$ Zob. K. Strzelecka, Szalom, 156.

40 Zob. Tamże, 157.

${ }^{41}$ Zob. Tamże, 159.
} 
(zob. $1 \mathrm{Krl}$ 8,15-20;29). Kolejną ważną przestrzenią było święte Miasto Jeruzalem (zob. Iz 52,1), następnie Eretz Yisrael (Joz 5,15; Za 2,16), i w pewnym sensie cały świat (zob. Wj 3,5) ${ }^{42}$. Prawo nakazywało, aby trzy razy $^{43}$, w poszczególnych okresach roku, związanych ze świętami, udawać się z pieszą pielgrzymką do świętego miasta ${ }^{44}$, aby tam $\mathrm{w}$ świątyni YHWH oddać mu chwałę. Obowiązek ten dotyczył zarówno tych, którzy mieszkali w Ziemi Izraela, jak i tych którzy żyli w diasporze. Każdy Izraelita miał stanąć na wzgórzu świątynnym, aby YHWH, spojrzawszy na niego, błogosławił mu. Wedle tradycji (zob. 2 Krn 3,1) jest nim to samo miejsce, w którym Abraham składał w ofierze swojego syna Izaaka ${ }^{45}$. Nadał on wtedy temu miejscu nazwę; „Pan widzi” (zob. Rdz 22,14), gdyż „do świątyni idzie się zarówno po to, by być widzianym, jak i po to by widzieć" ${ }^{36}$. Oddaje to pewien stan ducha, który towarzyszył idącym z pielgrzymką i obchodzącym święta. Chodziło o to, by w spotkaniu z Bogiem poddać się jego przenikającemu widzeniu i otworzyć się na jego wypełniającą obecność. Duchowemu przeżywaniu tych wydarzeń towarzyszyło składanie konkretnych materialnych ofiar (zob. Pwt 16,16-17). Konsekwentne zachowywanie i przestrzeganie tych nakazów pozwalało doświadczać świętości przeżywanego czasu, wypełnionego Bożą obecnością. Prowadziło też do coraz większego zaufania w Bożą opatrzność. Wszelki dar bowiem od Niego pochodzący do Niego również wraca ${ }^{47}$. Patrząc na sposób przeżywania świąt obchodzonych przez Izraelitów zauważamy, że każde $\mathrm{z}$ nich zawierało ideę poświęcenia jakiegoś fragmentu czasu (poprzez wyłączenie go z codziennego użytku) i ofiarowania go YHWH na wyłączność. Każde z nich zawierało też jakieś wspomnienie wydarzeń w których widać interwencje YHWH w historię Narodu ${ }^{48}$.

${ }^{42}$ Por. A. Malina, Świętość ziemi, Jerozolimy i świątyni w czasach Nowego Testamentu (Kelim 1,6-9), „Collectanea Theologica” 74 (2004) 2, 64.

${ }^{43}$ Zob. Pwt 16,16; Wj 23,17.

${ }^{44}$ Zob. J. Klinkowski, Idea przestrzeni, czasu i człowieka w Biblii, 81.

${ }^{45}$ Zob. C.H. Miller, Jerozolima, w: Encyklopedia biblijna, red. P.J. Achtemeier, tłum. Z. Kościuk, Warszawa 2000, 454.

${ }^{46}$ Zob. Brat Efraim, Jezus Żyd praktykujący, tłum. J. Fenrychowa, Kraków 1994, 326.

47 Por. Tamże.

${ }^{48}$ Zob. J. Klinkowski, Idea przestrzeni, czasu i człowieka $w$ Biblii, 83. 
Sięgając do genezy najważniejszych świąt biblijnego Izraela trzeba powiedzieć, że zostały one przejęte od ludów starożytnych, pierwotnie miały charakter rolniczy, a Naród Wybrany wcielił je w swoją kulturę i nadał im nowego znaczenia ${ }^{49}$. To co wyznaczało cykl świąteczny dla ludów starożytnych to rytm roku związany z wydarzeniami (często rolniczymi), które miały miejsce w świecie przyrody. Pierwotnie święto Pesech (Święto Paschy), które upamiętniało wyjście Narodu z niewoli egipskiej, było świętem wiosny. Z kolei Szawuot (Święto Tygodni), obchodzone pod koniec okresu żniw pszenicy (zob. Wj 23,16; 34,22), wcześniej było świętem plonów, a z czasem stało się pamiątką podarowania Narodowi Tory na górze Synaj. Natomiast Sukkot (Święto Szałasów), wcześniej święto winobrania, Izraelowi miało przypominać czas jego tułaczki po pustyni i zamieszkiwanie w szałasach (zob. Kpł 23,42n) ${ }^{50}$. Izrael w tworzącym się kalendarzu religijnym, nadawał nowe znaczenie dotychczasowym odniesieniom ludów pierwotnych do sił politeistycznych. Wszelkie odniesienia ukazujące jakieś „boskie” działania, zostały stopniowo przekształcane na w obchody pamięci wydarzeń o których opowiada Objawienie. Rytm życia Narodu wytyczały praktykowane obrzędy uświęcające poszczególne momenty czasowe ${ }^{51}$.

\section{1. ŚWIĘTO PASCHY}

Świętem, które z czasem stało się najważniejszym ze wszyst-

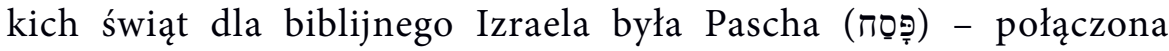

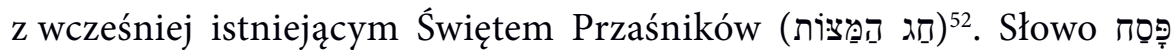

spotykamy po raz pierwszy w Wj 12,13.23.27, kiedy Mojżesz zapowiada obchodzenie jej, jeszcze przed wyjściem z niewoli egipskiej. Święto to wywodzi się z dużo wcześniejszej tradycji nomadycznej, obchodzonej

49 Por. G. Kołodziej, Sacrum Szabatu, 94.

${ }_{50}$ Zob. A.J. Heschel, Szabat, 29-30.

${ }^{51}$ Por. P. Grelot, M. Join Lambert,, Czas, w: Słownik Teologii Biblijnej, red. X. Leon-Defour, tłum. K. Romaniuk, Poznań 1990, 177.

${ }_{52}$ Więcej na ten temat zob. B.W. Matysiak, Historiozbawczy charakter izraelskich świąt pielgrzymkowych, „Studia Warmińskie” 41-42 (2004-2005), 194-197. 
na wiosnę $e^{53}$. Pomijając wszystkie skomplikowane szczegóły związane z jego genezą, tradycje Pięcioksięgu wiążą Święto Przaśników (Wj 23,15; 34,18; Pwt 16,3), Paschę (Pwt 16,1-6), czy w końcu Paschę i Przaśniki (Wj 12,23-27.39; 12,12-13), z wydarzeniem wyjścia $\mathrm{z}$ niewoli egipskiej. Zauważamy to w sposób szczególny w Wj 12, który zawiera jednoznaczne przesłanie mówiące o tym, że celebracje te $\mathrm{z}$ jednej strony przynosiły $\mathrm{Na}$ rodowi wybawienie, a $\mathrm{z}$ drugiej ich kultywowanie miało o nim nieustannie przypominać ${ }^{4}$. To YHWH był tym, który w konkretnym czasie wchodzi w historię Narodu. To On wyprowadza swoje stworzenie z niewoli; jest On tym, z którym Naród przez konkretne rytuały nawiązuje Przymierze, i w końcu to On jest tym, który prowadzi Naród ku zbawiennej przyszłości. Święto to związane z cyklem tygodniowym: „Pilnuj przestrzegania miesiąca Abib i święcenia Paschy ku czci Pana, Boga swego, gdyż w miesiącu Abib, nocą, Pan, Bóg twój, wyprowadził cię z Egiptu. (...) Sześć dni będziesz jadł przaśniki, a w siódmym dniu jest uroczyste zgromadzenie ku czci Pana, Boga twego: żadnej pracy nie będziesz wykonywał" (Pwt 16,1.8), nawiązuje do stwórczego dzieła YHWH, który pracował przez

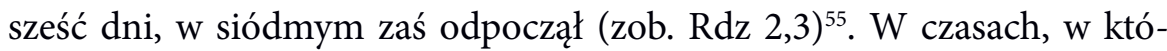
rych święto Paschy miało już charakter pielgrzymkowy i obchodzono je w Świątyni, niezwykłego rysu eschatologicznego nadaje mu zwyczaj otwierania drzwi świątyni przez kapłanów zaraz po północy ${ }^{56}$. Związane to było $\mathrm{z}$ przekonaniem, że po północy ma nadejść Mesjasz ${ }^{57}$. Naród w czasie Paschy wspominał czas wyjścia z Egiptu, ale patrzył z nadzieją w przyszłość, oczekując wybawienia $\mathrm{z}$ wszelkiej doświadczanej niewoli. Stała data obchodów święta wpisana w kalendarz liturgiczny na dzień 14/15 Nisan (zob. Wj 13,14) ${ }^{58}$, nadawała niezwykłego rytmu czasowego przypominającego o przymierzu, które YHWH zawarł z Narodem.

${ }^{53}$ Więcej na ten temat zob. Zob. J. Klinkowski, Idea przestrzeni, czasu i człowieka w Biblii, 86-87.

${ }^{54}$ Zob. R. de Vaux, Instytucje Starego Testamentu, 503-504.

${ }_{55}$ Zob. B.W. Matysiak, Historiozbawczy charakter izraelskich świąt pielgrzymkowych, 194.

${ }^{56}$ Por. J. Flawiusz, Antiquitates Judaice, XVIII, II,2.

57 Zob. B. Poniży, Ksiegga Mądrości. Od Egzegezy do teologii, Poznań 2000, 148.

${ }^{58}$ Księga Wyjścia podaje tu nazwę miesiąca Abib, który w późniejszym czasie przyjął nazwę babilońską Nizan. Zob. J. Drozd, Ostatnia Wieczerza, Katowice 1977, 15. 


\section{2. ŚWIĘTO TYGODNI}

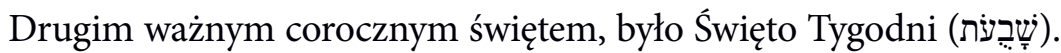
W Wj 23,16 nazwane jest ono żniwami (קִָּ (קָּר), natomiast Wj 34,22 nazywa

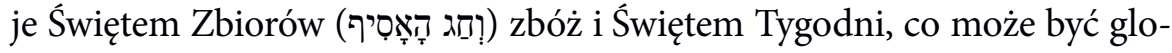
są łączącą to święto, z tym o którym mowa w Pwt 16,9-10. Księga Liczb 28,26 nazywa je Świętem Tygodni i Świętem Pierwocin (יוֹם הַבְּּּוּרים $)^{59}$. Szeroko rozbudowany rytuał tego święta odnajdujemy w Kpł 23,15-22, która precyzuje też datę obchodzenia go: „I odliczycie sobie od dnia po szabacie, od dnia, w którym przyniesiecie snopy do wykonania nimi gestu kołysania, siedem tygodni pełnych, aż do dnia po siódmym szabacie odliczycie pięćdziesiąt dni i wtedy złożycie nową ofiarę pokarmową dla Pana”. Święto to, było związane z Paschą, ponieważ data jego obchodzenia wyznaczona była po pięćdziesięciu dniach od jej zakończenia ${ }^{60}$. Odliczanie kolejnych dni zwane „obliczaniem omeru” miało charakter uroczysty. Do dziś ma to miejsce w synagodze każdego dnia po wieczornych modlitwach. Niektórzy przy tej okazji recytują również Ps 67. Uzasadnienie tej praktyki widzi się $\mathrm{w}$ budowie psalmu w wersji oryginalnej. Ma on bowiem siedem wierszy i czterdzieści dziewięć słów ${ }^{61}$. Treść tego psalmu, nawiązując do plonów otrzymywanych podczas żniw, ukazuje je nie jako najwyższe dobro, ale zapowiedź dóbr przyszłych ${ }^{62}$, co wzmacnia eschatologiczny wymiar istoty tego święta. Pierwotnie było to święto rolników prowadzących osiadły tryb życia. Izrael mógł je przejąć od Kananejczyków, kiedy zamieszkał w Ziemi Obiecanej. Tak jak w przypadku Paschy także Święto Tygodni w późniejszym okresie zostało związane $\mathrm{z}$ historią zbawienia. Idąc za informacją zawartą w Wj 19,1: „Było to w trzecim miesiącu od wyjścia Izraelitów

59 Zob. R. de Vaux, Instytucje Starego Testamentu, 504.

${ }^{60}$ Wyrażenie: „od dnia po szabacie”, dostarczyło wielu trudności interpretacyjnych, i różnego ich rozumienia. Dla faryzeuszy dniem, od którego rozpoczynano liczenie był 15 Nisan. Dniem święta był więc zawsze 6 Siwan. Według Saduceuszy i kręgów kapłańskich liczenie winno rozpoczynać się od dnia, który następował po najbliższym szabacie, następującym po święcie Paschy i dlatego zawsze przypadał w niedzielę. Por. E. Testa, Usi e riti degli Ebrei ortodossi, Jerusalem 1973, 116.

${ }^{61}$ Zob. M. Strassfeld, The Jewish Holidays. A Guide and Commentary, New York $1985,49$.

${ }^{62}$ Por. S. Łach, Księga Psalmów. Wstęp - przekład z oryginału - komentarz ekskursy, t. 7, cz. 2, Poznań 1990, 313. 
z Egiptu; w tym dniu przybyli [oni] na pustynię Synaj” dowiadujemy się, że Naród przybył pod Synaj w trzecim miesiącu po swym wyjściu z Egiptu, które rozpoczęło się w połowie pierwszego miesiąca. Dzień ten zaczęto traktować jako święto na pamiątkę nadania Tory na Synaju, czyli zawarcia przymierza YHWH z Izraelem ${ }^{63}$. Występujące w powyższym fragmencie sformułowanie „w tym dniu” może oznaczać, iż dzień ofiarowania Tory nigdy nie może stać się przeszłością, jest on „tym” dniem, każdym dniem $^{64}$. Interpretacja ta wskazuje, że czas jest wypełniony nieustanną obecnością YHWH. W opisie tego święta zawartym w Pwt wybrzmiewa także wymiar uświęcenia czasu $\mathrm{w}$ aspekcie wyzwolenia. Odnajdujemy go w Pwt 16,12, gdzie YHWH wyraźnie poucza Izraela: „Przypomnisz sobie, żeś był niewolnikiem w Egipcie, dlatego będziesz przestrzegał tych praw". Natomiast odwołanie się do aspektu stworzenia pojawia się w opisie tego święta na kartach Księgi Kapłańskiej: „Tego samego dnia zwołacie lud. Będzie to dla was zwołanie święte. Nie będziecie wykonywać tego dnia żadnej pracy. Jest to ustawa wieczysta we wszystkich waszych siedzibach, dla waszych pokoleń" (Kpł 23,21). Jest to wyraźna informacja odwołująca się do siódmego dnia, w którym YHWH odpoczął po dziele stworzenia (por. Rdz 2,3). Uniwersalizm tego świętego czasu, jakim jest Szawuot, potwierdzony zostaje określeniem „ustawa wieczysta”, jak i samą jego nazwą.

\section{3. ŚWIĘTO NAMIOTÓW}

Trzecim wielkim świętem o charakterze pielgrzymkowym było Święto Namiotów. Znane było już ono w starożytnym Szilo, a z relacji Józefa Flawiusza dowiadujemy się, że i w jego czasach miało ono niezwykle ważne znaczenie dla Hebrajczyków ${ }^{65}$. W starszych kalendarzach kultowych znajdujących się w Wj 23,16 i 34,22 nazwane jest ono Świętem Zbiorów

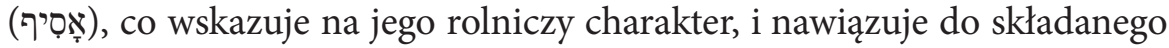

${ }^{63}$ Por. A. Paciorek, Obyczajowość życia wspólnotowego, w: Życie społeczne w Biblii, red. G. Witaszek, Lublin 1998, 306.

${ }^{64}$ Komentarz do: Szemot 19:1, w: Tora Pardes Lauder. Księga Druga Szemot, red. S. Pecaric, tłum. S. Pecaric, E. Gordon, t. 2, Kraków 2003, 176.

${ }_{65}$ Zob. J. Flawiusz, Antiquitates Judaicae, VIII, II,1. 
dziękczynienia Bogu za zbiory winogron i innych plonów. Obchodzono je jesienią. Z późniejszej tradycji wiemy, że rozpoczynało się 15 . dnia siódmego miesiąca (zob. Kpł 23,34; Lb 29,12). Po siedmiu dniach trwania święta, kolejny dzień mający charakter najbardziej uroczysty kończył cały obchód. W nakazie siedmiodniowego trwania święta (zob. Kpł 23,41; Pwt 16,15), odnajdujemy wymiar uświęcania czasu w aspekcie stworzenia, do którego nawiązuje długość jego trwania. W kalendarzach kultowych młodszych (Pwt 16,13-15) święto występujące pod nazwą „Namiotów” (תפĐo), również nawiązuje do jego rolniczego charakteru. Tak nazwa, jak i późniejszy zwyczaj stawiania szałasów wywodzi się prawdopodobnie z praktyki ich budowania na czas zbiorów w winnicach i sadach. Pierwotnie spełniały one rolę praktyczną, a z czasem stały się nieodłącznym elementem związanym z obchodami święta ${ }^{66}$. Podobnie jak święto Paschy i Tygodni, tak i to święto, w późniejszym czasie zaczęto wiązać $\mathrm{z}$ historią zbawienia. Łączono je z wędrówką Narodu po pustyni Synaj i związanym $\mathrm{z}$ nią zamieszkiwaniem w tym czasie $\mathrm{w}$ namiotach (por. Kpł 23,43) ${ }^{67}$. Kiedy nastąpiła centralizacja kultu w Jerozolimie, budowanie szałasów stało się nieodłącznym elementem celebracji tego święta (zob. Kpł 23,42; Ne 8,16). Wymiar uświęcenia czasu $\mathrm{w}$ aspekcie wyzwolenia i przymierza widać w zaproszeniu, skierowanym przez YHWH do Narodu, do świętowania. Ma to przypominać kolejnym pokoleniom o Jego ingerencji w historię Izraela. To On, YHWH, wyprowadził lud z Egiptu - z niewoli, i to On prowadził lud przez pustynię uświęcając ten czas wyzwolenia i prowadzenia: „Wszyscy tubylcy Izraela będą mieszkali w szałasach, aby pokolenia wasze wiedziały, że kazałem Izraelitom mieszkać w szałasach, kiedy wyprowadziłem ich z ziemi egipskiej. Ja jestem Pan, Bóg wasz!» (Kpł 23,42-44). Kiedy Żyd wchodzi podczas święta do szałasu, to na nowo aktualizuje czas niezwykłych wydarzeń przeszłości, które stają się teraźniejszością ${ }^{68}$. Wydarzenia przypominane i uobecniane $\mathrm{w}$ tym czasie odnawiają na nowo przymierze, które YHWH zawarł ze swoim Narodem ${ }^{69}$. Do wydarzeń, które miały

${ }^{66}$ Por. T. Brzegowy, Doroczne święta pielgrzymkowe Izraela, „Ruch Biblijny i Liturgiczny" 36 (1983) 2,108.

${ }^{67}$ Zob. B.W. Matysiak, Historiozbawczy charakter izraelskich świąt pielgrzymkowych, 203.

${ }_{68}$ Zob. Brat Efraim, Jezus Żyd praktykujacy, 379.

${ }^{69}$ Por. J. Klinkowski, Idea uświęcenia przestrzeni, czasu i człowieka w Biblii, 88. 
miejsce na pustyni mogła nawiązywać późniejsza ceremonia zapalania wieczornej lampy na Dziedzińcu Kobiet w świątyni jerozolimskiej, co było wspomnieniem ognistego słupa, prowadzącego Naród wędrujący po pustyni (zob. Wj 13,21) ${ }^{70}$. Znany był również zwyczaj procesyjnego przynoszenia wody z sadzawki Siloe, którą jako symbol życia wylewano uroczyście na ołtarzu $\mathrm{w}$ świątyni ${ }^{71}$. Ten gest miał na celu przypomnienie, że to YHWH jest źródłem wszelkiego życia ${ }^{72}$. Czynność ta mogła nawiązywać do momentu, w którym Mojżesz spowodował wytryśnięcie wody na pustyni, stając się pośrednikiem zatroskanego YHWH o swój wyzwolony $\mathrm{z}$ niewoli lud, zaspakajającego jego pragnienie (Wj 17,1-7 ${ }^{73}$.

Uświęcenie czasu w wymiarze eschatologicznym ukazują teksty prorockie Za 14 i Ez 47. W wizjach tych Święto Namiotów nabierało znaczenia Mesjańskiego. Zachariasz głosi, że na końcu czasów wszystkie narody przybędą do świątyni Jerozolimskiej na Święto Namiotów (zob. Zach 14,16-19). Będzie to też dzień w którym wypłyną ze świątyni strumienie żywej wody, a to da życie całej ziemi (zob. Zach 14,8; Ez 47,1-12) ${ }^{74}$. Wobec powyższego zauważamy, że święto to, nie tylko uobecniało wydarzenia przeszłe, uświęcając teraźniejszość, ale również odnosiły się do wydarzeń, które miały nadejść.

\section{ZAKOŃCZENIE}

Trzy wielkie święta biblijnego Izraela należały do najważniejszych momentów, które wyznaczały rytm całego roku. Ich wyjątkowość polegała nie tylko na tym, że duchowo odmieniały zwykłą codzienność, lecz przede wszystkim ze względu na treść, jaką ze sobą niosły. Przed-

${ }^{70}$ Zob. S. Mędala, Chrystologia Ewangelii św. Jana, Kraków 1993, 308.

${ }^{71}$ Zob. J. Musielak, Nowotestamentowe odniesienia do święta Szałasów, w: Verbo Domini servire opuscula Ioanni Cantio Pytel septuagenario dedicata, red. F. Lenort, T. Siuda, Poznań 2000, 82.

${ }^{72}$ Por. A. Tronina, Panie abym przejrzał! Ślepota i niewola $w$ biblii, Lublin 1997, 136.

${ }^{73}$ Zob. D. Szojda, Woda żywa, w: Egzegeza Ewangelii św. Jana. Kluczowe teksty i tematy teologiczne, red. F. Gryglewicz, Lublin 1992, 284.

${ }^{74}$ Zob. M. Wróbel, Znaczenie i obchody Święta Namiotów w Starożytnym Izraelu, „Scripta Biblica et Orientalia” 3 (2011), 103. 
stawione tutaj zagadnienia dotyczące głównych świąt biblijnego Izraela w kontekście czasu ukazane zostało w świetle świętości i wyjątkowości czasu Szabatu, zaś z jego studium, w oparciu o teksty biblijne, wyłoniły się trzy zasadnicze aspekty dotyczące uświęcenia czasu. Są to: celebracja stworzenia i wyzwolenia, eschatologia oraz znak przymierza. Te trzy tematy są wspólnym mianownikiem łączącym te cztery wydarzenia. Uświęcenie czasu Paschy, Święta Tygodni i Święta Namiotów objawia się w obecności tych duchowych wymiarów historii Izraela: stworzenia i wyzwolenia, eschatologii oraz przymierza. Każde z tych trzech świąt jest zatem aktualizacją charakteru i znaczenia samego Szabatu, zwielokrotnieniem w przestrzeni czasu uświęconego przez YHWH w dziele stworzenia. Te bezpośrednie konotacje omawianych Świąt z Szabatem wskazują na ich wymiar ponadprzestrzenny, transcendentny i przemieniający. Tak rozumiane święto staje się stanem ducha, a nie jedynie miejscem czy aktem. To zaś jest odpowiedzią na pytanie, jak rozumieć i przeżywać czas w kontekście Boga.

Streszczenie. Zagadnienie czasu w perspektywie przestrzeni liturgicznej Izraela jest ważne i w bardzo konkretny sposób wysuwa się przed porządek przestrzeni i zewnętrznej obrzędowości. Celem tego artykułu jest przedstawienie głównych świąt biblijnego Izraela, takich jak: Paschy, Święta Tygodni i Święta Namiotów w ich relacji do Święta Świąt, czyli Szabatu. Każde z tych trzech świąt jest zatem aktualizacją charakteru i znaczenia samego Szabatu, zwielokrotnieniem w przestrzeni czasu uświęconego przez YHWH w dziele stworzenia. Te bezpośrednie konotacje omawianych Świąt z Szabatem wskazują na ich wymiar ponadprzestrzenny, transcendentny i przemieniający. Tak rozumiane święto staje się stanem ducha, a nie jedynie miejscem czy aktem.

Słowa kluczowe: Izrael; Szabat; Pascha; Święto Tygodni; Święto Namiotów; czas.

Abstract. Sanctification of time in the major feasts of biblical Israel. Time in the perspective of the liturgical space of Israel is important and in a very concrete way comes out ahead of the order of space and external ritual. The purpose of this article is to present the main feasts of biblical Israel, such as the Passover, the Feast of the Weeks, and the Feast of the Tabernacles, in their relation to the Feast of the Sabbath. Each of these three festivals is an actualization of the nature and significance of the Shabbat itself. It is a multiplication in the space of time sanctified by YHWH in the work of creation. These direct connotations of the feasts discussed with the Sabbath point to their transcendent dimension. Such a feast is a state of mind, and not only a place or an act.

Key words: Israel; Sabbath; Feast of the Weeks; Feast of the Tabernacles; time. 


\section{BIBLIOGRAFIA}

Achteimer, P.J., Unterman, J., Czas, w: Encyklopedia biblijna, red. P.J. Achtemeier, tłum. A. Gocłowska, Warszawa 1999, 180-181.

Brat Efraim, Jezus Żyd praktykujacy, tłum. J. Fenrychowa, Kraków 1994.

Brzegowy, T., Doroczne święta pielgrzymkowe Izraela, „Ruch Biblijny i Liturgiczny” 36 (1983) 2, 98-115.

Drozd, J., Ostatnia Wieczerza, Katowice 1977.

Flawiusz, J., Antiquitates Judaice.

Grelot, P., Join Lambert, M., Czas, w: Słownik Teologii Biblijnej, red. Leon-Defour, X., tłum. K. Romaniuk, Poznań 1990.

Grunfeld, I., Szabat, tłum. I. Mańka-Marcisz, Kraków 2011.

Heschel, A.J., Man Is Not Alone. A Philosophy of Religion, New York 1951.

Heschel, A.J., Szabat i jego znaczenie dla współczesnego człowieka, tłum. H. Halkowski, Kraków 2009.

Kameraz-Kos, N., Święta i obyczaje Żydowskie, Warszawa 1997.

Klinkowski, J., Idea przestrzeni, czasu i człowieka w Biblii, „Legnickie Wiadomości Diecezjalne" 16 (2007) 2, 78-100.

Koch, K., מוֹעָ, w: Theological Dictionary of the Old Testament, red. G.J. Botterweck, H. Ringgren, H.-J. Fabry, Grand Rapids 1997, t. 8, 167-173.

Kołodziej, G., Sacrum Szabatu, „Łódzkie Studia Teologiczne” 5 (1996), 93-101.

Kronholm, T., עֵת, w: Theological Dictionary of the Old Testament, red. G.J. Botterweck, H. Ringgren, H.-J. Fabry, Grand Rapids 2001, t. 11, 434-451.

Kudasiewicz, J., Poznawanie Boga Ojca. Szkice z teologii biblijnej, t. 1, Kielce 2000.

Łach, S., Księga Psalmów. Wstęp - przekład z oryginału - komentarz - ekskursy, t. 7, cz. 2, Poznań 1990.

Malina, A., Świętość ziemi, Jerozolimy i świątyni w czasach Nowego Testamentu (Kelim 1,6-9), „Collectanea Theologica 74 (2004) 2, 63-81.

Matysiak, B.W., Historiozbawczy charakter izraelskich świąt pielgrzymkowych, „Studia Warmińskie" 41-42 (2004-2005), 193-204.

Matysiak, B.W., Szabat dniem uświęcenia ludu JHWH, w: Bóg jest miłościa 1J 4,16. Studia dla Księdza Profesora Józefa Kudasiewicza w 80. rocznice urodzin, red. Waldemar Chrostowski, Warszawa 2006, 278-293.

Mędala, S., Chrystologia Ewangelii św. Jana, Kraków 1993.

Miller, C.H., Jerozolima, w: Encyklopedia biblijna, red. P.J. Achtemeier, tłum. Z. Kościuk, Warszawa 2000, 442-455.

Musielak, J., Nowotestamentowe odniesienia do święta Szałasów, w: Verbo Domini servire opuscula Ioanni Cantio Pytel septuagenario dedicata, red. F. Lenort, T. Siuda, Poznań 2000, XXX

Paciorek, A., Obyczajowość życia wspólnotowego, w: Życie społeczne w Biblii, red. G. Witaszek, Lublin 1998, 291-332.

Poniży, B., Księga Mądrości. Od Egzegezy do teologii, Poznań 2000. 
Preuss, H.D., עוֹ עים we Theological Dictionary of the Old Testament, red. G.J. Botterweck, H. Ringgren, H.-J. Fabry, Grand Rapids 1999, t. 10, 530-545.

Ruppert, L., Symbole im Alten Testament, w: Freude am Gottesdienst, red. J. Schreiner, Stuttgart 1983, 93-105

Schreiner, J., Die Zehn Gebote im Leben des Gottesvolkes, München 1988.

Słownik symboliki biblijnej, red. L. Ryken, J.C. Wilhoit, T. Longman II, Warszawa 1998.

Strassfeld, M., The Jewish Holidays. A Guide and Commentary, New York 1985.

Strzelecka, K., Szalom, Warszawa 1987.

Szojda, D., Woda żywa, w: Egzegeza Ewangelii św. Jana. Kluczowe teksty i tematy teologiczne, red. F. Gryglewicz, Lublin 1992.

Testa, E., Usi e riti degli Ebrei ortodossi, Jerusalem 1973.

Tora Pardes Lauder. Ksiega Druga Szemot, red. S. Pecaric, tłum. S. Pecaric, E. Gordon, Kraków 2003, t. 2.

Tora Pardes Lauder. Ksiega Pierwsza Bereszit, red. S. Pecaric, tłum. S. Pecaric, E. Gordon, Kraków 2001, t. 1.

Tronina, A., Panie abym przejrzat! Ślepota i niewola w biblii, Lublin 1997.

Vaux, R., Instytucje Starego Testamentu, tom I i II, tłum. Tadeusz Brzegowy, Poznań 2004. Vries, S.P. De, Mzn., Obrzędy i symbole Żydów, tłum. A. Borowski, Kraków 2004.

Wróbel, M., Znaczenie i obchody Święta Namiotów w Starożytnym Izraelu, „Scripta Biblica et Orientalia" 3 (2011), 99-107.

Zając E., Judaizm jako religia uświęcająca czas, „Ethos” 99 (2012), 45-60. 